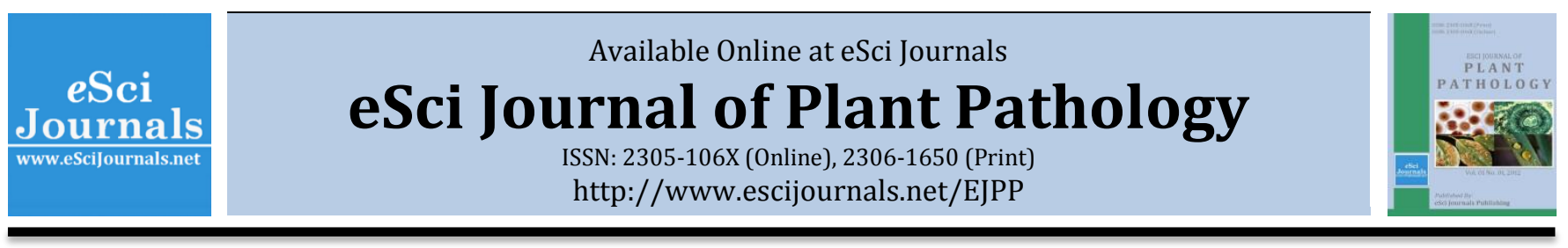

\title{
INDUCTION OF SYSTEMIC RESISTANCE BY BIOCONTROL AGENTS AGAINST BACTERIAL BLIGHT OF COTTON CAUSED BY XANTHOMONAS CAMPESTRIS PV. MALVACEARUM
}

\author{
aVinay B. Raghavendra*, bLokesh Siddalingaiah, cNagesh K. Sugunachar, bChandra Nayak, \\ bNiranjana S. Ramachandrappa \\ a Department of Biotechnology, Teresian College, Mysore, India. \\ $\mathbf{b}$ Department of Studies in Botany, University of Mysore, Manasagangotri, Mysore, India. \\ c Department of Studies in Biotechnology, University of Mysore, Manasagangotri, Mysore, India.
}

\section{A B S T R A C T}

Bioagents such as Trichoderma harzianum, Pseudomonas fluorescens and Bacillus subtilis were isolated from cotton rhizosphere soil and tested individually for their effectiveness in controlling bacterial blight of cotton caused by Xanthomonas campestris pv. malvacearum $(\mathrm{Xcm})$. Talc based formulations were prepared and used for seed treatment at different concentrations for assessing their ability to stimulate plant growth and to control bacterial blight disease. Among bioagents, $P$. fluorescens and T. harzianum proved to be effective in controlling disease under field conditions. Other than direct action, these bioagents triggered the defense related enzymes involved in synthesis of phenols. Higher activity of peroxidase, phenylalanine ammonia-lyase, polyphenol oxidase and $\beta$-1,3-glucanase was observed in $P$. fluorescens and T. harzianum treated cotton plants after challenge inoculation with $\mathrm{Xcm}$. Seed treatment with these bioagents enhanced the seed germination and growth parameters against blight disease and they also induced systemic resistance in plant for defense mechanisms.

Keywords: Cotton, Xanthomonas campestris pv. malvacearum, bioagents, induced systemic resistance, defense enzymes.

\section{INTRODUCTION}

Cotton (Gossypium spp.) is an important fiber crop and India ranks first in area which is over 88 lakh hectares. India ranks only fourth in production in the world. Production has shot up since 1996-97 from 50 lakh bales to 116 lakh bales (Mishra and Krishna, 2001). Diseases are the chief constraints in cotton production. Among the different diseases, bacterial blight of cotton (BBC) caused by Xanthomonas campestris pv. malvacearum (Smith) Dye $(\mathrm{Xcm})$ causes considerable yield loss in cotton growing areas of the country. In Karnataka an average loss of 20-25 per cent is reported in this disease. The standard chemical recommendation consisting of antibiotics plus copper oxychloride through recommended is not much effective unless this is taken up right at the initial stage of this disease and it requires repeated applications for combating the disease. This leads to environmental pollution,

* Corresponding Author:

Email: viragh79@gmail.com

(C) 2012 eSci Journals Publishing. All rights reserved. development of resistance by the pathogen and residual toxicity. Alternatively, bioagents constitute an ecofriendly approach with long lasting protection, avoiding the problems emanating from the use of chemicals. Due to variation in climatic conditions the importance of the disease also varies from place to place. The normal practice for the management of the plant diseases is through chemical means. However, this method has various limitations including environmental pollution, development of resistance in the pathogen, etc. The current approach is mainly to developing alternate and newer methods or strategies for the management of disease. Due to variation in climatic conditions the importance of the disease also varies from place to place. Review of literature indicated the lack of new approaches with special reference to the management of the disease. Survey and estimation of crop loss in field conditions is very much important in agriculture. To explore the seed-borne pathogens in different agroclimatic situations as well as to demarcate the disease free areas for quality seed 
production. It can provide information about the status, location of a disease and economic loss. One of the reasons is that the quantitative severity loss relationships have no conceptual framework for crop loss assessment. Disease incidence, disease severity and crop loss have seldom been applied to bacterial diseases in cotton. Induced resistance can be defined as active defense based on physical and chemical barriers elicited by preliminary inoculation with pathogens or no-host pathogens, or by application of metabolic products from such organisms. It acts against subsequent infection by otherwise pathogenic organisms. In a broader sense the term also includes resistance induced by abiotic stimuli. So, present study mainly focused on the induction of peroxidase (PO), polyphenol oxidase (PPO), phenylalanine ammonia lyase (PAL), and $\beta$-1, 3-glucanase activities in cotton seedlings by Trichoderma harzianum, P. fluorescens and B. subtilis against Xanthomonas campestris pv. malvacearum.

\section{MATERIALS AND METHODS}

Isolation of bioagents from cotton rhizosphere soil and mass multiplication: Bioagents viz., Trichoderma harzianum, Bacillus subtilis and Pseudomonas fluorescens were isolated from healthy cotton rhizosphere soil obtained from the experimental plots of cotton Research Station, Hebballi, Dharwad district of Karnataka. A talc-based powder formulation of $P$. fluorescens and B. subtilis was developed based on the procedures of Vidhyasekaran et al. (1997) using a mixture of $10 \mathrm{~g}$ of carboxymethylcellulose and $1 \mathrm{~kg}$ of talc. The $\mathrm{pH}$ was adjusted to 7.0 by adding calcium carbonate and the mixture was autoclaved for $30 \mathrm{~min}$. $P$. fluorescens was grown in King's $\mathrm{B}$ broth and $B$. subtilis in Nutrient broth for $48 \mathrm{~h}$ as shake cultures in an automatic rotary shaker at $150 \mathrm{rpm}$ under room temperature of $25 \pm 2^{\circ} \mathrm{C}$ and $400 \mathrm{ml}$ of bacterial suspension, containing $1 \times 10^{8}$ colony forming units (cfu) per ml was added to $1 \mathrm{~kg}$ of the talc material, mixed well under sterile conditions, packed in polythene bags and sealed. This formulation was stored at $5^{0} \mathrm{C}$ for one month, and used in the present study. Conidia of $T$. harzianum isolated from 10-day-old cultures on potato dextrose agar and the spore load was adjusted to $10^{5}$ spores $/ \mathrm{ml}$ haemocytometrically. The spore suspension was centrifuged at $100 \mathrm{rpm}$ for 15 minutes, supernatant was discarded and the pellets were air dried for $24 \mathrm{~h}$ and used as the potential source of bioagents (Howell et al., 1997).
Seed inoculation with $\mathbf{X c m}$-18: Representative strain of Xanthomonas campestris pv. malvacearum race-18 were obtained from the central institute of cotton research (CICR) Nagpur, India was used for this experiment. Surface disinfected cotton seeds (susceptible cultivar LRA-5166) with $1 \%$ sodium hypochlorite $(\mathrm{NaOCl})$ for 2 min followed by repeated washing with sterile distilled water were inoculated by soaking in $\mathrm{Xcm}$ suspension $\left(1 \times 10^{8} \mathrm{cfu} / \mathrm{ml}\right)$ for $4 \mathrm{~h}$ and dried over blotting paper for $1 \mathrm{~h}$ at room temperature. These $\mathrm{Xcm}$ inoculated seeds were subjected to further experiments.

Effect of bioagents on seed germination and seedling vigour: Bioagents treated and untreated seeds were subjected to paper towel method and incubated at $25 \pm 2^{0} \mathrm{C}$ under alternate cycles of $12 / 12$ hour darkness and light for a period of 14 days. On the final day of incubation, the seed germination percentage was assessed and the vigour index was calculated based on the following formula as described by (Abdul Baki and Anderson, 1973). (Mean root length + Mean shoot length) $\mathrm{x}$ Percentage seed germination Effect of bioagents under field condition: In the other experiment, treated seeds were sown in field with a known quantity of fertilizers. Further, on 10, 20 and 30 days after sowing, seedlings were sprayed with the suspensions of $T$. harzianum, $P$. fluorescens and $B$. subtilis and untreated seeds served as control were also maintained in the experimental plots in triplicates. Four replicates of 100 seeds were used for each treatment. On the 40, 60 and 80 day after inoculation, plants were evaluated for disease incidence based on lesion size and number of infected leaves /plant, following the 0-4 scale (Sheo Raj, 1988). The percent disease incidence (PDI) was calculated based on the formula:

$$
P D I=\frac{\text { Total numerical grade } \times 100}{\text { Number of leaves scored } \times \text { maximum grade }}
$$

Plant height, plant girth, number of bolls per plant, average boll weight, was recorded on $90^{\text {th }}$ day after sowing.

Assay of induced enzymes: Based on the preliminary observations in seed germination test, throughout the experiments, 7-day-old seedlings raised in a sand bed placed in plastic trays were sprayed with two day old culture suspension of $\mathrm{Xcm}$ at the concentration of $1 \mathrm{x}$ $10^{8} \mathrm{cfu} / \mathrm{ml}$. Seedlings were harvested after 7 days of inoculation and used for the extraction of peroxidases, phenylalanine ammonia lyase (PAL), polyphenol oxidase (PPO) and $\beta$-1, 3-glucanase assay. Protein was 
estimated based on the procedure described by Bradford (1976).

Tissue collection: The challenge inoculation of $\mathrm{Xcm}$ inoculated cotton seedlings treated with bioagents and water were collected at various time intervals of 0,12 , $24,48,72$, and $96 \mathrm{~h}$ after pathogen inoculation and quickly frozen in liquid nitrogen and stored at $-80^{\circ} \mathrm{C}$.

Peroxidase assay (POX, E.C.1.11.1.7): Peroxidase was extracted in $100 \mathrm{mM}$ sodium phosphate buffer ( $\mathrm{pH} 7.0$ ) and was assayed as described by Hammerschmidt and Kuc (1982). The reaction mixture (3 ml) consisted of $0.25 \%(\mathrm{v} / \mathrm{v})$ guaiacol in $10 \mathrm{mM}$ potassium phosphate buffer (pH 6.9) containing $10 \mathrm{mM}$ hydrogen peroxide. The reaction was initiated by adding $5 \mu$ of crude enzyme extract and which was measured spectrophotometrically at $470 \mathrm{~nm}$ (Hitachi U 2000, Japan). Peroxidase activity was expressed in terms of the change in absorbance at $470 \mathrm{~nm}$ in the linear phase of the slope (absorbance @ $470 \mathrm{~nm} \mathrm{~min}^{-1} \mathrm{mg}^{-1}$ protein).

Phenylalanine ammonia lyase assay (PAL, E.C. 4.1.3.5): PAL from seedlings was extracted in $25 \mathrm{mM}$ sodium borate buffer ( $\mathrm{pH}$ 8.8) containing $32 \mathrm{mM} \beta$ mercaptoethanol. PAL was assayed as described by Lisker et al. (1983) using t-cinnamic acid as standard. The reaction mixture was incubated at $40^{\circ} \mathrm{C}$ for 2 hour and the reaction was arrested by the addition of $60 \mu \mathrm{l}$ of $5 \mathrm{~N} \mathrm{HCl}$. The absorbance at $290 \mathrm{~nm}$ was read against the same volume of reaction mixture without Lphenylalanine. The enzyme activity was expressed in terms of $\mu \mathrm{mol}$ of trans-cinnamic acid $\mathrm{mg}^{-1}$ protein $\mathrm{h}^{-1}$.

Polyphenol oxidase assay (PPO, E.C. 1.14): PPO was extracted in $0.1 \mathrm{M}$ Tris-HCL buffer ( $\mathrm{pH}$ 7.0) containing $0.1 \mathrm{M} \mathrm{KCl}, 1 \%(\mathrm{v} / \mathrm{v})$ TritonX-100, 1mM EDTA and 5\% (w/v) PVPP (polyvinylpolypyrrolidine) following the procedures of Mayer et al. (1965). The reaction mixture $3 \mathrm{ml}$ consisted of $10 \mathrm{mM}$ pyrocatechol (1, 2dihydroxybenzene) in $100 \mathrm{mM}$ potassium phosphate buffer ( $\mathrm{pH}$ 6.5). The reaction was initiated by adding $100 \mu \mathrm{l}$ of crude enzyme extract and which was measured spectrophotometrically at $515 \mathrm{~nm}$ was recorded for $1 \mathrm{~min}$ at $25^{\circ} \mathrm{C}$. The PPO activity was

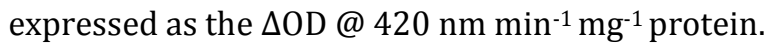

Estimation of $\boldsymbol{\beta}-\mathbf{1}, \mathbf{3}$ glucanase (E.C. 3.2.1.39): $\beta-1,3$ glucanase activity was estimated according to the method described by Pan et al. (1989) with glucose as standard. Laminarin (Sigma) was dissolved in $0.05 \mathrm{M}$ sodium acetate buffer ( $\mathrm{pH}$ 5.2) to get $0.1 \%$ concentration and used as the substrate. Crude enzyme $(50 \mu \mathrm{l})$ was incubated with substrate for $15 \mathrm{~min}$ at $37^{0}$
C. The enzyme-substrate reaction was stopped by adding $0.5 \mathrm{ml}$ of DNS reagent by boiling for $10 \mathrm{~min}$, later $2.0 \mathrm{ml}$ distilled water was added to each tube and the product released was estimated for reducing groups at $540 \mathrm{~nm}$. The enzyme activity was expressed in terms of $\mu$ mole of glucose $\mathrm{min}^{-1} \mathrm{mg}^{-1}$ protein. The experiment was repeated three times.

Estimation of phenolic substances: Total phenol content was estimated according to the procedures of Malick and Singh (1980). 0.5g seedlings were ground with a pestle and mortar in ten times volume of $80 \%$ ethanol. The homogenate was centrifuged at 10,000 rpm for $10 \mathrm{~min}$, supernatants were pooled and evaporated to dryness. The residue was dissolved in 5 $\mathrm{ml}$ distilled water and used to estimate the phenols. The reaction mixture contained $0.2 \mathrm{ml}$ of extract mixed with $0.5 \mathrm{ml}$ of Folin-Ciocaulteau's reagent. After 3 minutes, $2 \mathrm{ml}$ of $20 \%$ sodium carbonate solution was added. Contents were mixed thoroughly and placed in the boiling water bath for $1 \mathrm{~min}$. Contents were cooled and absorbance was read at $650 \mathrm{~nm}$ in a double beam UV-visible spectrophotometer (Hitachi U-2000, Japan). Standard curve was prepared using different concentrations of gallic acid. Phenol content of the extract was expressed as mg phenol/g material and the entire experiment was repeated thrice for each treatment.

Protein estimation: Protein estimation of all the enzyme extracts were carried out by dye binding method (Bradford, 1976) using bovine serum albumin as a standard.

Statistical analysis: The data from laboratory and greenhouse experiments were analyzed separately for each experiments which were subjected to arcsine transformation and analysis of variance (ANOVA) (SPSS, version 10.0). Significant effects of treatments were determined by the magnitude of $\mathrm{F}$ value $(P=0.05)$. Treatment means were separated by Turkey's HSD test.

\section{RESULTS}

Irrespective of three bioagents, isolated from rhizosphere soil were evaluated for their effect on germination and seedling vigor over control (Fig. 1) clearly indicates that the seed treatment with biological agents enhanced the seed germination. Maximum germination and enhancement of seedling vigor was noticed in the plants due to treatment with $P$. fluorescens $(78 \%)$ and T. harzianum (76\%) followed by B. subtilis $(73 \%)$ respectively, whereas the control showed $71 \%$. There was improved vigor index up to 
2186 in P. fluorescens followed by T. harzianum and $B$. subtilis with a vigor of 2171and 2169 respectively compared to its respective control 2110. Seed treatment with bioagents separately resulted in the accumulation of PR proteins such as $\beta-1,3$, glucanase, Phenylalanine ammonia lyase, polyphenol oxidase and peroxidases. P. fluorescens and T. harzianum induced more peroxidase activity after $24 \mathrm{~h}$ of challenge inoculation with $\mathrm{Xcm}$ and remained significantly higher from 48 to $96 \mathrm{~h}$. B. subtilis also enhanced the peroxidase activity significantly compared to control but lesser to that of P. fluorescens and T. harzianum (Fig. 2).

Fig. 1. Effect of bioagents on cotton seed germination and seedling vigor under laboratory conditions

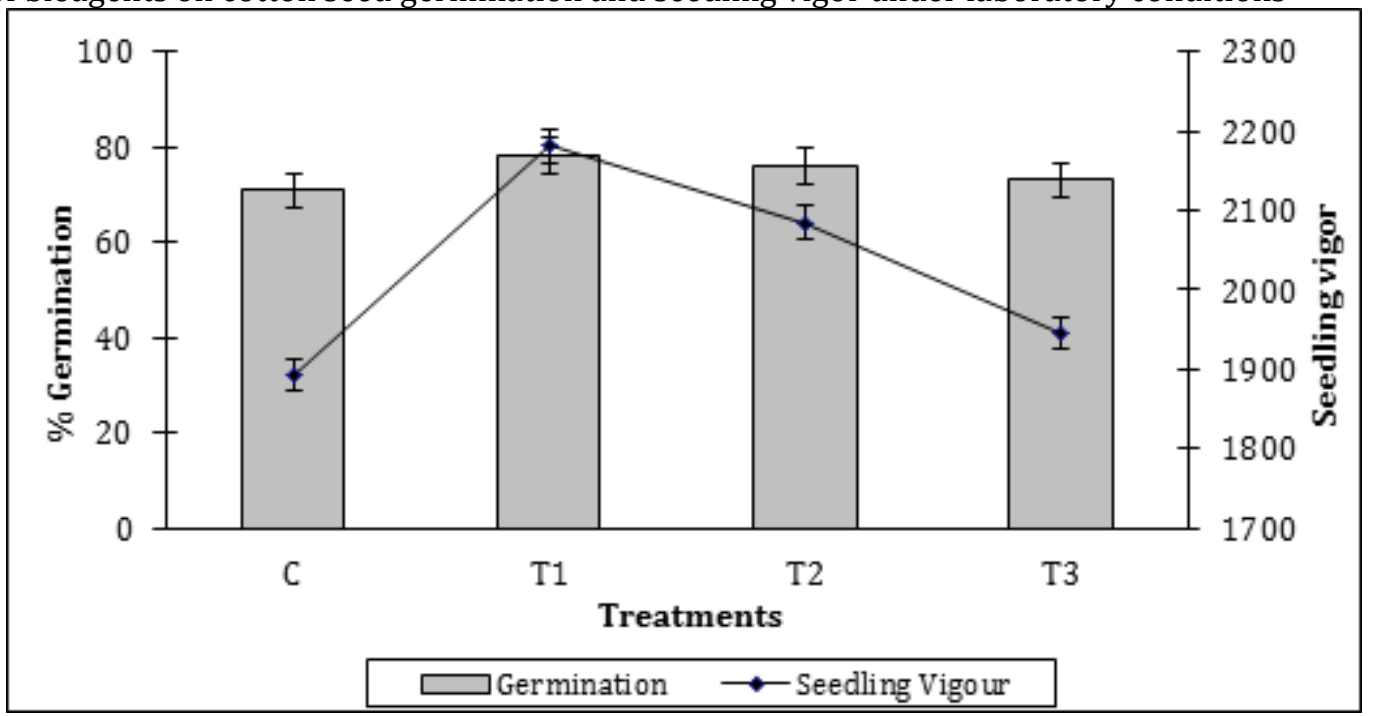

$\mathrm{C}=$ Control, $\mathrm{T} 1=$ Pseudomonas fluorescens, $\mathrm{T} 2=$ Trichoderma harzianum $\mathrm{T} 3=$ Bacillus subtilis.

$\pm \mathrm{SE}=$ Standard Error of the mean

Fig. 2. Variation in the activity of peroxidase (PO) in the cotton seedlings due to bioagent treatments against $X \mathrm{~cm}$

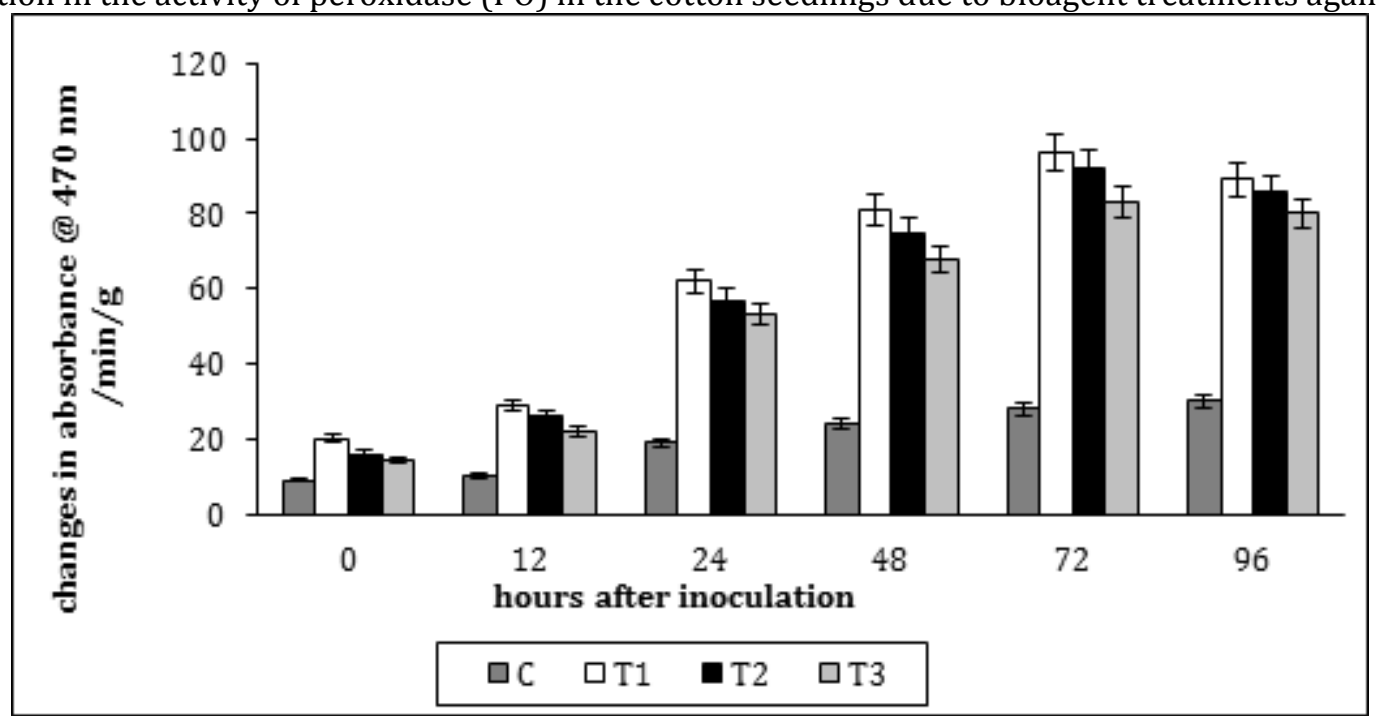

$\mathrm{C}=$ Control, $\mathrm{T} 1=$ Pseudomonas fluorescens, $\mathrm{T} 2=$ Trichoderma harzianum $\mathrm{T} 3=$ Bacillus subtilis.

Xcm $=$ Xanthomonas campestris pv malvacearum

$\pm \mathrm{SE}=$ Standard Error of the mean

The PAL, PPO and $\beta$-1, 3-glucanase activities after challenge inoculation remained constant till $96 \mathrm{~h}$. PAL activity was enhanced and it reached a maximum at $24 \mathrm{~h}$ after challenge inoculation with $\mathrm{Xcm}$ declined drastically after $48 \mathrm{~h}$ and remained constant at $96 \mathrm{~h}$ (Fig. 3). Increased activity of PPO was observed due to 62 bioagents and higher activity was recorded up to $72 \mathrm{~h}$ but declined at $96 \mathrm{~h}$ (Fig. 4). A significant increase in the activity of $\beta-1,3$, glucanase observed in cotton seedlings treated with $P$. fluorescens and $T$. harzianum increases at $72 \mathrm{~h}$ when challenge inoculation with the Xcm (Fig. 5). The untreated control showed very less 
activities of PAL, PPO, $\beta-1,3$, glucanase and peroxidases. Under greenhouse conditions, the $P$. fluorescens $T$. harzianum and B. subtilis treated seeds enhanced the seed germination and plant growth. The disease incidence was significantly reduced when compare to control, treated with water. Mean disease incidence was reduced after 60 days after sowing (DAS) to 72, 68 and 68\%, respectively (Fig. 6).

Fig. 3. Role of bioagents on the Phenylalanine ammonia lyase (PAL) activity in seedlings of cotton challenged with Xcm

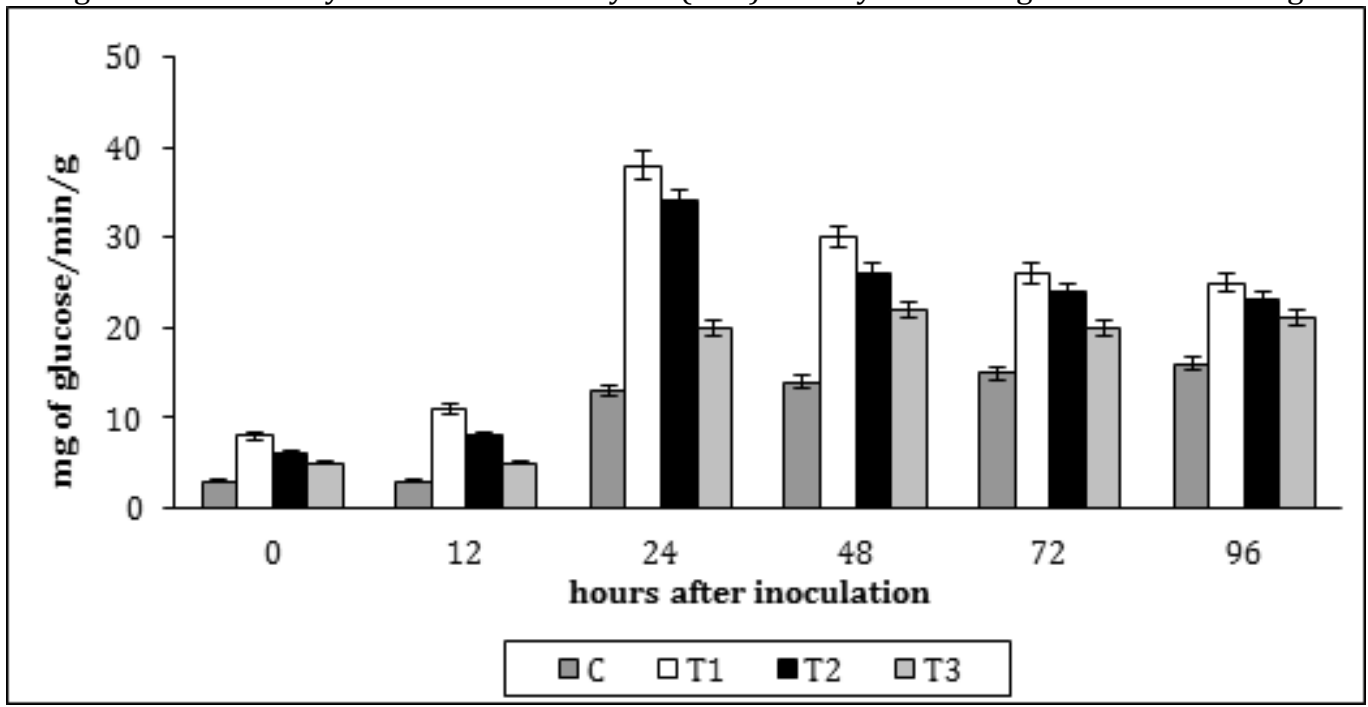

$\mathrm{C}=$ Control, $\mathrm{T} 1$ = Pseudomonas fluorescens, $\mathrm{T} 2=$ Trichoderma harzianum $\mathrm{T} 3=$ Bacillus subtilis

Xcm = Xanthomonas campestris pv malvacearum

$\pm \mathrm{SE}=$ Standard Error of the mean

Fig. 4. Variation in the activity of polyphenol oxidase (PPO) in the cotton seedlings due to bioagent treatments against Xcm

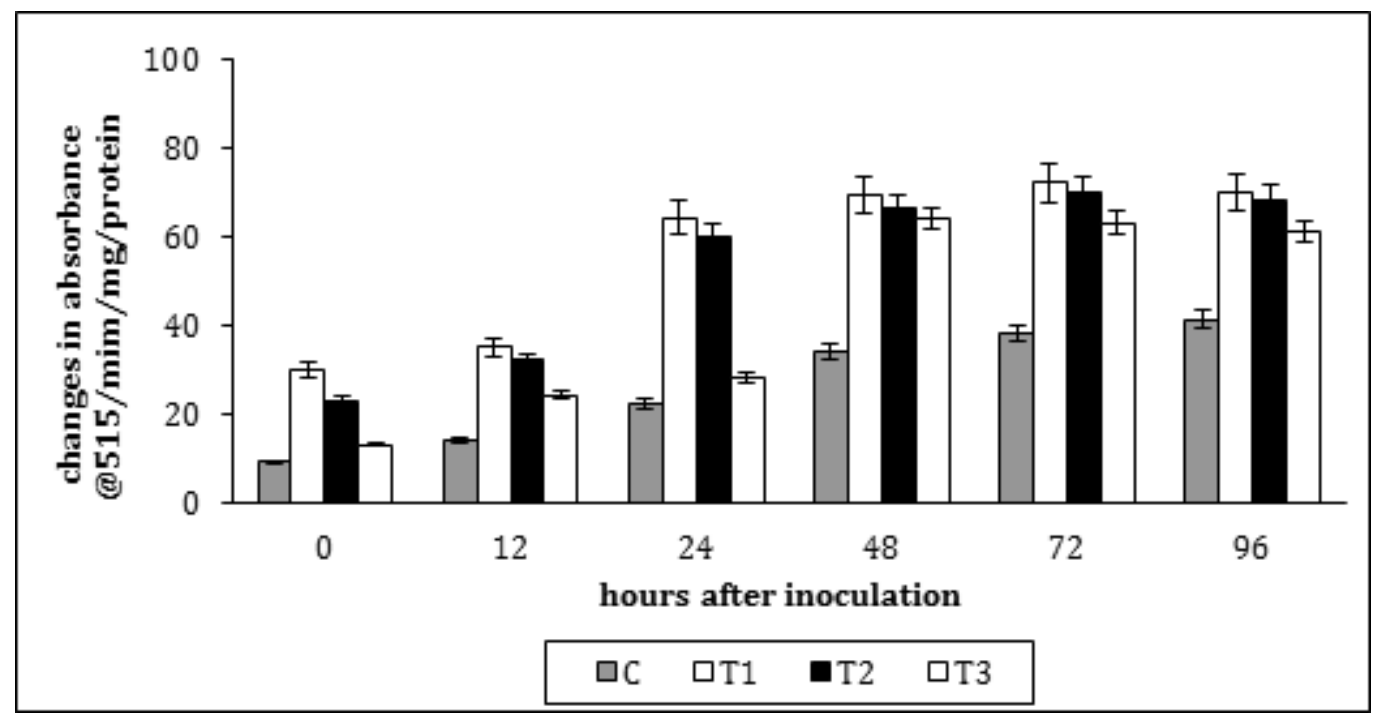

$\mathrm{C}=$ Control, $\mathrm{T} 1$ = Pseudomonas fluorescens, $\mathrm{T} 2=$ Trichoderma harzianum $\mathrm{T} 3$ = Bacillus subtilis.

Xcm $=$ Xanthomonas campestris pv malvacearum

$\pm \mathrm{SE}=$ Standard Error of the mean

Total phenol content was found increased in $P$. fluorescens $(0.0030 \mathrm{mg} / \mathrm{g}), \mathrm{T}$. harzianum (0.0028), $B$. subtilis (0.0026), treated samples compared to that of control showed (0.0020) (Fig 7). The foliar spray of bioagents at 20 days intervals enhanced the boll numbers and their biomass (Table 1). Optimum level resulted in the highest boll weight, $4.0 \mathrm{~g}$ by the treatment of $P$. fluorescens, and also improved growth attributes pertaining to plant height, stem girth, number of bolls/plant and weight of the boll. Next found to be increased in T. harzianum, B. subtilis, when compared with control. 
Table 1. Influence of bioagent treatments on the growth and yield of cotton

\begin{tabular}{ccccc}
\hline Treatments & $\begin{array}{c}\text { Plant height } \\
\text { (cm) }\end{array}$ & $\begin{array}{c}\text { Stem girth } \\
\text { (cm) }\end{array}$ & No. of bolls/plant & $\begin{array}{c}\text { Boll weight } \\
\text { (g) }\end{array}$ \\
\hline C & $72 \pm 0.57^{\mathrm{e}}$ & $7.0 \pm 0.33^{\mathrm{bcd}}$ & $5 \pm 0.577^{\mathrm{c}}$ & $3.8 \pm 0.58^{\mathrm{b}}$ \\
T1 & $78 \pm 0.57^{\mathrm{e}}$ & $7.7 \pm 0.33^{\mathrm{bcd}}$ & $7 \pm 0.577^{\mathrm{c}}$ & $4.3 \pm 0.58^{\mathrm{b}}$ \\
T2 & $75 \pm 0.57^{\mathrm{e}}$ & $7.4 \pm 0.577^{\mathrm{bcd}}$ & $6+0.577^{\mathrm{bc}}$ & $4.1 \pm 0.58^{\mathrm{c}}$ \\
T3 & $75 \pm 0.57^{\mathrm{de}}$ & $7.3 \pm 0.577^{\mathrm{cd}}$ & $6 \pm 0.577^{\mathrm{bc}}$ & $4.0 \pm 0.58^{\mathrm{bc}}$ \\
\hline
\end{tabular}

$\mathrm{C}=$ Control, $\mathrm{T} 1=$ Pseudomonas fluorescens, $\mathrm{T} 2=$ Trichoderma harzianum $\mathrm{T} 3=$ Bacillus subtilis.

Data based on three replicates. According to Duncan's Multiple Range Test (DMRT), values followed by same letters are not significantly different at $\mathrm{P} \leq 0.05$.

$\pm \mathrm{SE}=$ Standard Error of the mean

Fig. 5. Influence of bioagents in the enhanced activity of $\beta$-1, 3-glucanase in cotton seedlings challenged with $X \mathrm{~cm}$

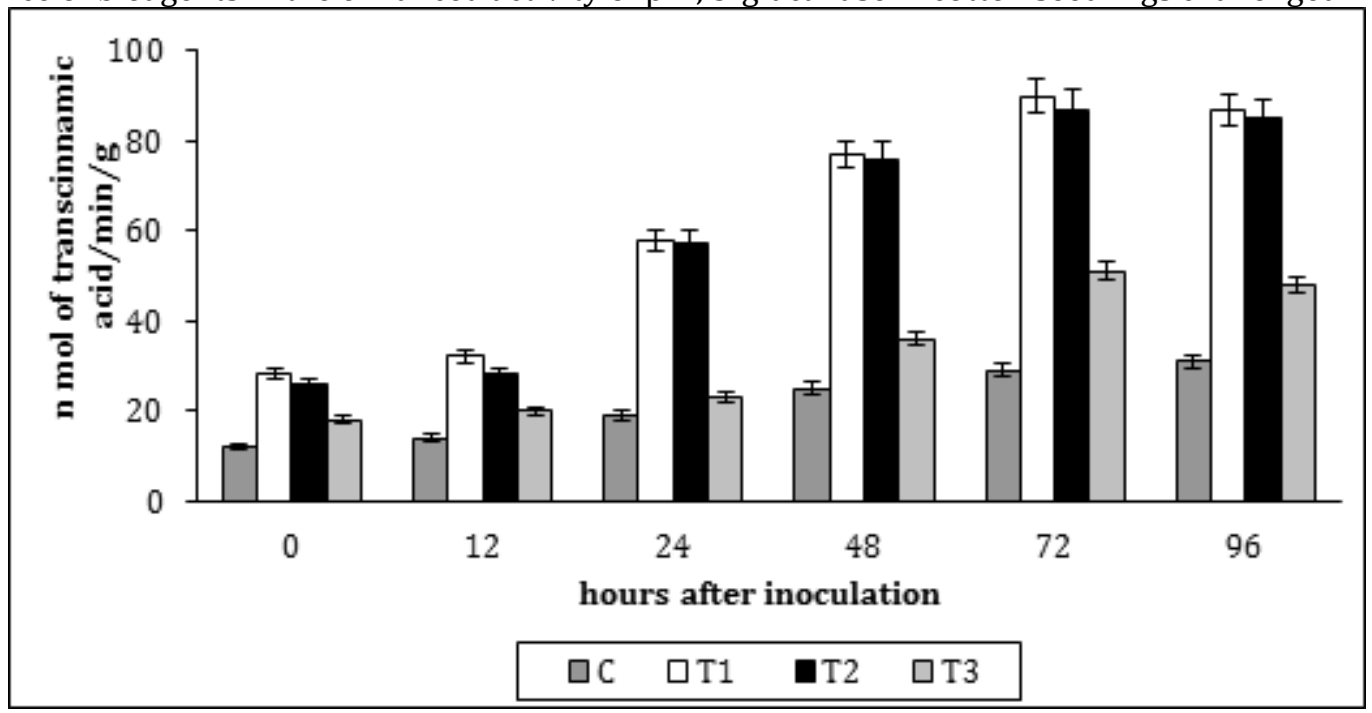

$\mathrm{C}=$ Control, $\mathrm{T} 1=$ Pseudomonas fluorescens, $\mathrm{T} 2=$ Trichoderma harzianum $\mathrm{T} 3=$ Bacillus subtilis

Xcm = Xanthomonas campestris pv malvacearum

$\pm \mathrm{SE}=$ Standard Error of the mean

Fig. 6. Effect of bioagents on bacterial blight incidence of cotton under field conditions

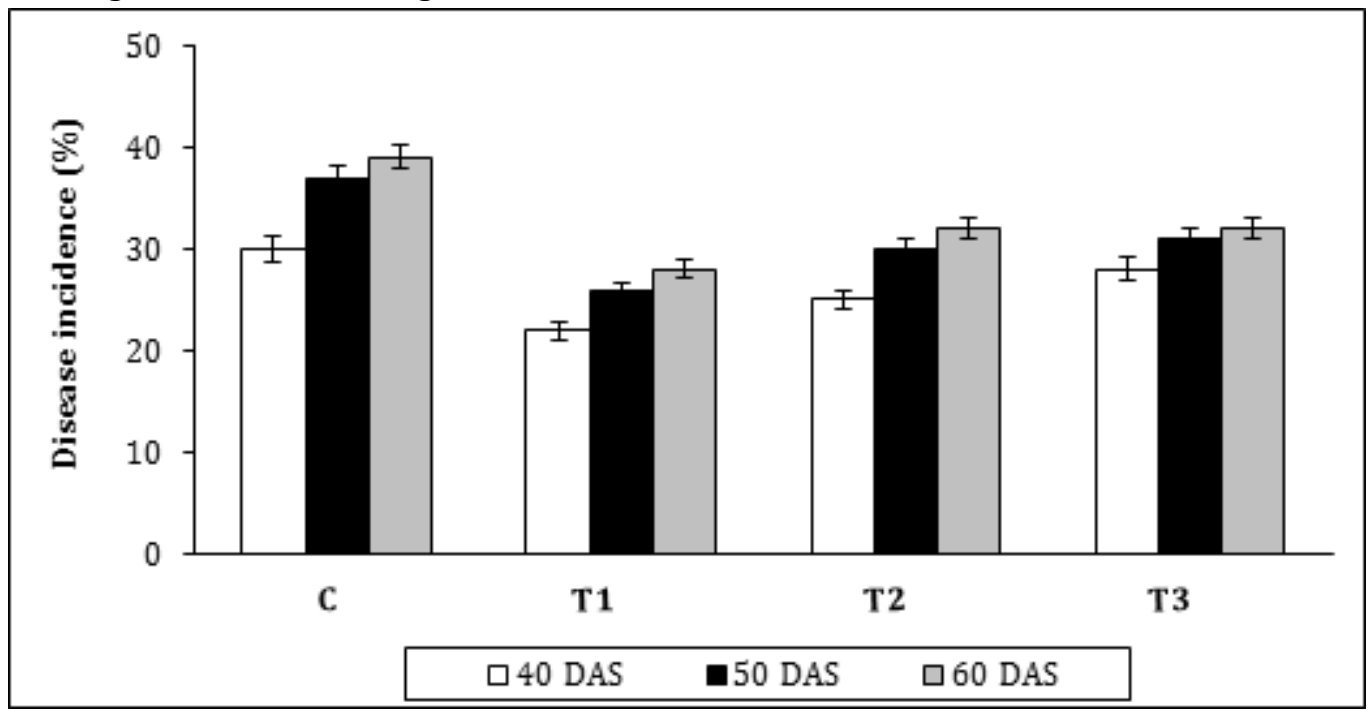

$\mathrm{C}=$ Control, $\mathrm{T} 1=$ Pseudomonas fluorescens, $\mathrm{T} 2=$ Trichoderma harzianum $\mathrm{T} 3=$ Bacillus subtilis.

$\pm \mathrm{SE}=$ Standard Error of the mean

DAS= Days after sowing 
Fig 7. Variation in total phenol content in the treated samples of cotton.

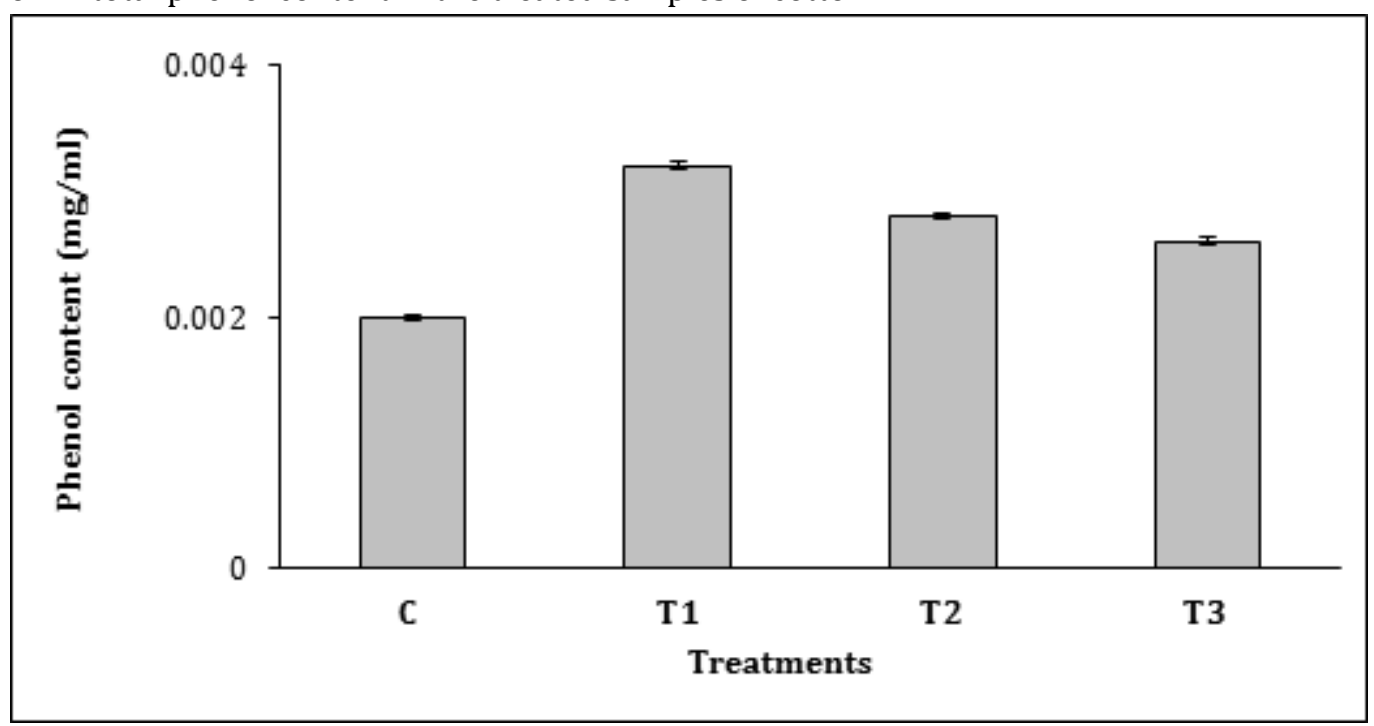

$\pm \mathrm{SE}=$ Standard Error of the mean

It shows that all bioagents have a capacity to decrease the disease in turn enhanced the plant growth quality parameters. P. fluorescens and T. harzianum stood superior over $B$. subtilis in the reduction of disease incidence.

\section{DISCUSSION}

Bioagents are reported to produce hydrolytic enzymes viz., chitinase, $\beta$-1, 3-glucanase, proteases, volatile and non-volatile antibiotics (Elad et al., 1982). Pseudomonas fluorescens showed their antibiotic activities through the production of secondary metabolites or siderophores or cyanide or pyrollonitrin which are known to suppress the root-rot causing fungus in cotton (Laha and Verma, 1998). Increased peroxidase activity, high level of mRNAs encoding for phenylalanine ammonia lyase was reported during the interaction between host plants and various bacterial endophytes, occurred as indicated by Zdor and Anderson (1992). Peroxidase is an useful marker of plant development, physiology, infection and stress (Zhang and Kirkham, 1994; Welinder, 1992). Tissues of many plants release phenolic compounds and active oxygen species like peroxidase up on infection with several fungi, have the unique role in the signal transduction system and induce the resistance in plants. Vidhyasekaran (1997) reviewed that the peroxidase activity was more in the plants over infection by the pathogens in some plants and it has great role in inhibit the pathogen development. Peroxidase contributes to resistance by oxidation of phenolic compounds in cotton was reported by
Martinez et al. (1996). Maximum reduction in disease was noticed in the cotton plants due to treatment with $P$. fluorescens and T. harzianum followed by B. subtilis. The disease reduction might be attributed to the suppression of the activity of pathogen in the host and soil by the antagonists through their over colonization (Cook, 1991). P. fluorescens reported to play a main role in controlling both pre-emergence and post emergence mortality of beans (Kataria et al., 1997). Promising effects of T. harzianum in the induction of terpenoid synthesis in cotton roots and control of Rhizoctonia solani were explained by Howell et al. (2000). Gupta (2000) reported the Plant growth-promoting Bacillus subtilis strain as potential inducer of systemic resistance in tomato against Fusarium wilt. Present findings are in support of the present findings with respect to enhanced growth of plants due to bioagents. Among the bioagents, $P$. fluorescens and T. harzianum stood superior gave promising results in increasing plant height, number of bolls, boll weight, plant girth over B. subtilis. P. fluorescens strain is known to induce the activities of phenylalanine ammonia-lyase, chitinase and $\beta-1,3$ glucanase and accumulation of phenolics It was observed to be involved in the suppression of symptoms of bacterial disease in rice (Meena et al., 1999). Increase in PAL and reduce the disease incidence of Fusarium wilt in pigeon pea was observed by the treatment with Bacillus subtilis AF1 (Podile and Laxmi, 1998). In the present study, bioagents showed differences in the degree of protection against bacterial blight. Each bioagents activates different defense mechanisms within the reduced resistance pathway 
and resulted in difference in the reduction of disease. Mondel (1999) reported that the rhizobacteria from indigenous cotton, which enhanced seed germination through the suppression of bacterial blight disease. Bioagents are known to successfully prevent the pathogenic activity of many plant pathogenic bacteria. They increase the respiration that may have adverse effect on pathogenic bacteria at tissue level, as the consequences they increased the germination. Main role of bioagents is the involvement of cytoplasmic leakage and cellulase from the pathogen. Antibiotics present or released by the bioagents are also responsible for inhibiting the growth of target pathogen.

Plants have defense genes that need appropriate stimuli or signals to activate them. Inducing the plants for their own defense mechanisms by prior application of abiotic or biotic inducer is a novel technique for plant protection. The inducers are known to accumulate signaling molecules, leading to increased expression of defense genes encoding chitinase, 1,3-glucanase, peroxidase and other enzymes involved in the synthesis of phytoalexins (M'Piga et al., 1997). Induced Systemic Resistance (ISR) of plants against pathogens is a widespread phenomenon that has been intensively investigated with respect to the underlying signalling pathways as well as to its potential use in plant protection. Elicited by a local infection, plants respond with a salicylic-dependent signalling cascade that leads to the systemic expression of a broad spectrum and long-lasting disease resistance that is efficient against fungi, bacteria and viruses. Salicylic acid (SA) has an important role in the signalling pathway leading to ISR. After infection, endogenous levels of SA increase locally and systemically, and SA levels increase in the phloem before ISR occurs. SA is synthesized in response to infection both locally and systemically; de novo production of SA in non-infected plant parts might therefore contribute to systemic expression of ISR (Heil and Bostock, 2002). Compared to pathogens inducing SAR, non-pathogenic rhizobacteria inducing ISR trigger a different signal transduction pathway not dependent on the accumulation of the SA and activation of Pathogensis-related (PR)-genes but dependent on precipitation of ethylene and jasmonic acid (Van Loon, et al., 1998). The plant growth promoting Pseudomonas strains, which induced resistance systematically in watermelon to gummy stem rot, are investigated on their induced systemic resistance (ISR) - related characteristics by Lee et al. (Lee et al., 2001). Their work supports the concept that PGPR can protect plants against the pathogens by inducing defense mechanisms by iron-binding siderophore, HCN and other associates. The plant growth promoting rhizobacteria induced systemic protection against Tomato late blight (Yan et al., 2002).

These bioagents induced defense in cotton at varied levels of efficiency in the suppression of pathogen establishment or multiplication depending upon the ability of the pathogen to avoid activated host defenses. High peroxidase activity was observed with $P$. fluorescens and T. harzianum treatment followed by $B$. subtilis and control are associated with the stages of infection process and are involved in the generation of hydrogen peroxides, which inhibit the pathogen directly by producing free radicals with antimicrobial effects and lignifications (Hammerschmidt et al., 1982). Delannoy et al. (2003) reported the activity of Class III Peroxidases in the defense of cotton against the bacterial blight. Phenylalanine ammonia-lyase (PAL) and 4-coumarate: CoA ligase (4CL) is also serves as key enzyme in the biosynthetic pathway of lignin (Vidhyasekaran, 1997). PPO activity also enhanced due to treatment with bioagents and it catalyse the last step of biosynthesis of lignin and other oxidative phenols as described by Mauch and Staechelin (1989). Enzymatic pathways involving hydrolytic, oxidative, reductive, and substitution/transfer reactions are implicated in detoxification of cyanide by bacteria and fungi. The enzyme rhodanese from cyanogenic bacterium Pseudomonas aeruginosa involved in transfer reactions causes cyanide detoxification (Cipollone et al., 2008). The enzymes like chitinase, $\beta-1,3$ Glucanase and Cellulase are involved in antagonistic action of Pseudomonas against fungal pathogens (Saraf, et al., 2008). The enzyme formamide hydro-lyase is involved in HCN detoxification in sorghum infected by Gloeocercospora sorghi (Myers and Fry, 1978). PGPR offer an environmentally sustainable approach to increase crop production and health. The application of molecular tools is enhancing our ability to understand and manage the rhizosphere and will lead to new products with improved effectiveness (Nelson, 2004). Castresana et al. (1990) reported the considerable morphological changes including cytoplasmic disorganization and loss of protoplasmic content due to bioagents through the induction of phenolic substances. In the similar manner bioagents might have involved in 
induction of resistance constitutively against the pathogen attack. Several phenolics or phenolics phytoalexins are known to inhibit the growth of phytopathogenic bacteria, and growth retardation by phenolics has been considered an essential factor in polygenic resistance (Mohan and Mahadevan, 1996; Mondal et al., 2001; Niemann et al., 1994). It is easily imagined that these bioagents enhanced the antibacterial products, which restricts the development of challenging seed-borne and pathogenic bacteria.

In conclusion, present study suggest that the $P$. fluorescens and T. harzianum has strong adverse effect on $\mathrm{Xcm}$ and thus, reduced the bacterial blight In contrast, there was pronounced growth, recovery and productivity due to these bioagents through enhanced defense enzymes which involves in minimizing seedborne $X \mathrm{~cm}$ blight in cotton. Therefore, the present findings recommend the use of $P$. fluorescens and $T$. harzianum as potential agents in order to control bacterial blight in cotton.

\section{REFERENCES}

Kang, B.K., J.Y. Min, Y.S. Kim, S.W. Park, V.B. Nguyen and H.T. Kim. 2005. Semi-selective medium for monitoring Colletotrichum acutatum causing pepper anthracnose in the field. Res. Plant Dis. (in Korean) 11:21-27.

Abdul Baki, A. and J.D. Anderson. 1973. Vigor analysis in soybean seed by multiple criteria. Crop Sci. 13: 630-633.

Arora, Y.K. and K.L. Bajaj. 1985. Peroxidase and polyphenol oxidase associated with induced resistance of mung bean to Rhizoctonia solani Kuhn. Phytopathol. Zeitschrift. 114: 325-331.

Bradford, M.M. 1976. A rapid and sensitive method for quantification of microgram quantities of protein utilizing the principle of protein dye binding. Annals of Biochem. 72: 48-254.

Castresana, C., F. Carvalha, G. Gheysen, D. Habets and M. Van-Montagu. 1990. Tissue specific and pathogeninduced regulation of a Nicotiana plumbaginifolia $\beta-1,3$ glucanase and accumulation of phenolics in rice. Acta phytopathol. 34: 307-315.

Cook, R.J. 1991. Biological control of plant diseases: broad concepts and applications. In biological control of plant Diseases, FFTC Book series No. 42 pp. 1-29.

Cipollone, R., P. Ascenzi, P. Tomao, F. Imperi and P. Visca. 2008. Enzymatic Detoxification of Cyanide: Clues from Pseudomonas aeruginosa Rhodanese.
J. Mol. Microbiology and Biotechnology. 15 (2-3): 199-211.

Delannoy, E., A. Jalloul, K. Assigbetse, P. Marmey, J.P. Geiger, J. Lherminier, J.F. Daniel, C. Martinez and M. Nicole. 2003. Activity of Class III Peroxidases in the defense of cotton of bacterial blight. Mol. PlantMicrobe Interact. 16(11): 1030-1038.

Elad, Y., I. Chet and Y. Henis. 1982. Degradation of plant pathogenic fungi by Trichoderma harzianum. Can. J. Microbiology. 28: 719-725.

Gupta, V.P., H. Bochow, S. Dolej and Fischer. 2000. Plant growth-promoting Bacillus subtilis strain as potential inducer of systemic resistance in tomato against Fusarium wilt. Zeitschrift für Pflanzenkrankheiten und Pflanzenschutz. 107(2): 145-154

Hammerschmidt R., E.M. Nucldes and J. Kuc. 1982. Association of enhanced peroxidase activity with induced systemic resistance of cucumber to Colletotrichum lagenarium. Physiol. Mol. Plant. Pathol. 20: 73-82.

Heil, M. and R.M. Bostock. 2002. Induced Systemic Resistance (ISR) Against Pathogens in the Context of Induced Plant Defences. Ann. Bot. 89 (5): 503-512.

Howell, C.R., R.H. DeVay and B. Garber. 1997. Field of control of cotton seedling diseases with Trichoderma virens in combination with fungicides seed treatments. J. Cotton Sci. 1: 15-20.

Howell, C.R., R.D. Hanson, M. Stipanovic and J.S. Puckhaber. 2000. Induction of terpenoid synthesis in cotton roots and control of Rhizoctonia solani by seed treatment with Trichoderma virens. Phytopathol. 90: 248-252.

Howell, C.R. 2003. Mechanisms employed by Trichoderma species in the biological control of plant disease: The history and evolution of current concepts. Plant Dis. 87(1): 4-10.

Johri, B.N. 2001. Technology development and demonstration of a new bacterial inoculant (GRP3) for improved legume production. Uttar Pradesh Government, Project report.

Joseph, B., R.R. Patra and R. Lawrence. 2007. Characterization of plant growth promoting Rhizobacteria associated with chickpea (Cicer arietinum L). Int. J. Plant Prod. 1 (Suppl 2): 141152.

Kataria, H.R., B. Wilmsmeir and H. Buchenauer. 1996. Efficacy of resistance inducers free 
radial scavengers and an antagonistic strain of Pseuodomonas fluorescens for control of Rhizoctonia solani AG-4 in bean and cucumber. Plant Pathol. 46: 897-909.

Laha, G.S. and J.P. Verma. 1998. Role of fluorescent Pseudomonad's in suppression of root-rot and damping off of cotton. Ind. Phytopathol. 51(3): 275278.

Lata, A.K. and K.V. Tilak. 2002. Biofertilizers to augment soil fertility and crop production. In Soil Fertility and Crop Production Science Publishers, USA. Edited by Krishna KR. 279-312.

Lee, Y.H., W.H. Lee, D.K Lee and H.K. Shim. 2001. Factors relating to Induced Systemic Resistance in watermelon by Plant Growth-Promoting Pseudomonas spp. J. Plant Pathol. 17 (3): 174179.

Lugtenberg, B.J.J. and L.C. Dekkers. 1999. What makes Pseudomonas bacteria rhizosphere competent? Envir. Microbiology. 1 (Suppl 1): 9-13.

M'Piga, P., R.R. Belanger, T.C. Paulitz and N. Benhamou. 1997. Increased resistance to Fusarium oxysporum f. sp. radicis-lycopersici in tomato plants treated with the endophytic bacterium Pseudomonas fluorescens 63-28, Physiol. Mol. Plant. Pathol. 50: 301-320.

Malick, C. P. and M.B. Singh. 1980. Phenolics. In: Plant enzymology and histoenzymology. New Delhi: Kalyani Publishers.

Martinez, M., J.C. Baccou, E. Bresson, Y. Baissac, J. Daniel, A. Jalloul, J.L. Montillet, J.P. Geiger, K. Assigbetse and M. Nicole. 2000. Salicylic acid mediated by the oxidative burst is a key molecule in the local and systemic resistance of cotton challenged by an avirulent race of $\mathrm{Xcm}$ (race 18). Plant Physiol. 122: 757-766.

Mauch, F. and L.A. Staehelin. 1989. Functional implications of the subcellular localization of ethylene induced chitinase and $\beta$-1, 3-glucanase in bean leaves. Plant cell. 1:447-457.

Mayer, A.M., E. Harel and R.B. Shaul. 1965. Assay of catechol oxidase a critical comparison of methods. Phytochem. 5:783 - 789.

Meena, B., R. Radhajeyalakshmi, P. Vidhyasekaran and R. Velazhahan. 1999. Effect of foliar application of Pseudomonas fluorescens on activities of phenylalanine ammonia lyase, chitinase, $\beta-1,3-$ glucanase and accumulation of phenolics in rice. Acta Phytopathol. Ent. Hun. 34: 307-315.
Mehnaz, S., B. Weselowski, F. Aftab, S. Zahid, G. Lazarovits and J. Iqbal. 2009. Isolation, characterization, and effect of fluorescent pseudomonads on micropropagated sugarcane. Can. J. Micro. 55 (Suppl 8): 1007-1011.

Mishra, S.P. and A. Krishna. 2001. Assessment of yield losses due to bacterial blight of cotton. J. Mycology and Pl. Pathol. 31: 232-233.

Mohan, N. and A. Mahadevan. 1996. Effect of phenol on growth, respiration and ATP level of Xanthomonas oryzae pv. oryzae. In: Plant pathogenic bacteria: Proceedings of $9^{\text {th }}$ International Conference, CAS in Botany, university of Madras, Chennai, India. Pp. 481-486

Mondal, K.K. 1999. Beneficial effects of indigenous cotton Rhizobacteria on seed germinability growth promotion and suppression of bacterial blight disease. Ind. Phytopath. 52: 228-235.

Mondal, K.K., P. Dureja and J.P. Verma. 2001. Management of Xanthomonas campestris pv. malvacearumInduced blight of cotton through phenolics of cotton rhizobacterium. Cur. Microbiol. 43: 336-339

Myers, D.F. and W.E. Fry. 1978. Enzymatic release and metabolism of Hydrogen Cyanide in Sorghum infected by Gloeocercospora sorghi. J. Phytopathol. 68: 1717-1722.

Nelson, L.M. 2004. Plant growth promoting rhizobacteria (PGPR): Prospects for new inoculants. Online. Crop Manag. doi: 10.1094/CM-2004-0301-05-RV.

Niemann, G.J., H. Steiji, M. Geibel, D. Treutter and W. Feucht. 1994. Phenolics in the interaction of Pseudomonas sp./Dianthus caryophyllus/Fusarium oxysporum f.sp. dianthi. Acta Horticiltaria Netherlands. 381(2): 572-575

Pan, S.Q., X.S. Ye and J. Kuc. 1991. A technique for the detection of chitininase, $\beta-1,3$-glucanase and protein patterns after a single separation using polyacrylamide gel electrophoresis or isoelectro focusing. Phytopathol. 81: 970-974.

Podile, A.R. and V.D. Laxmi. 1998. Seed bacterization with Bacillus subtilis AF 1 increase phenylalanine ammonia-lyase and reduces the incidence of Fusarium wilt in pigeon pea. J. Phytopathol. 146: 255-259.

Rokhzadi, A., A. Asgharzadeh, F. Darvish, G. NourMohammadi and E. Majidi. 2008. Influence of plant growth promoting Rhizobacteria on dry matter accumulation of Chickpea (Cicer arietinum 
L) under field conditions. J. Agri. Envir. Sci. 3 (2): 253-257.

Saraf, M., A. Thakker and B.V. Patel. 2008. Biocontrol activity of different species of Pseudomonas against phytopathogenic Fungi In vivo and In vitro conditions. Int. J. Biotech. Biochem. 4 (Suppl $3 \& 4)$.

Sheo, R. 1988. Grading system for cotton diseases. CICR, Nagpur Bull. 1- 7.

Van-Loon, L.C., H.M. Bakker and M.J. Pieterse. 1998. Induction and expression of PGPR-mediated induced resistance against pathogens. Biol. Cont. Fungal Bacterial pl. pathog. 21 (9): 103-110.

Vidhyasekaran, P., R. Rabindran, M. Muthamilan, K. Nayar, K. Rajappan, N. Subramanian and M. Vasumathi. 1997. Development of a powder formulation of Pseudomonas fluorescens for control of rice blast. Pl. pathol. 46: 291-297.

Vidhyasekaran, P. 1997. Fungal pathogenesis in plants and crops: In: Marcel, Dekker, editors. Molecular Biology and Host defense Mechanisms. New york,
NY. Pp. 67-73.

Vidhyasekaran, P., N. Kamala, A. Ramanathan, K. Rajappan, V. Paranidharan and R. Velazhahan. 2001. Induction of systemic resistance by Pseudomonas fluorescens Pf1 against Xanthomonas oryzae pv. oryzae in Rice leaves. Phytopar. 29(2): 112.

Wani, P.A., M.S. Khan and A. Zaidi. 2007. Co-inoculation of nitrogen-fixing and phosphate-solubilizing bacteria to promote growth, yield and nutrient uptake in chickpea. Acta Agronomica Hungarica. 55 (3): 315323.

Yan, Z., M.S. Reddy, C. Ryu, J.A. McInroy, M. Wilson and J.W. Kloepper. 2002. Induced Systemic Protection Against Tomato Late Blight Elicited by Plant Growth-Promoting Rhizobacteria. The Amer. Phytopathol. Soci. 92 (12): 1329-1333.

Zdor, R.E. and A.J. Anderson. 1992. Influence of root colonizing bacteria on the defense responses of bean Pl. Soil. 140: 99-107. 